\title{
NETWORK STRUCTURE ANALYSIS FOR MULTICULTURAL INDUSTRIAL CNO
}

\author{
Michel Pouly, Mario Greber and Rémy Glardon \\ Ecole Polytechnique Fédérale de Lausanne (EPFL) \\ Laboratory for Production Management and Processes, Station 9, 1015 Lausanne, \\ SWITZERLAND \\ michel.pouly@epfl.ch, \\ Mario.greber@epfl.ch, remy.glardon@epfl.ch
}

\begin{abstract}
Emerging countries like China offer low wages, large production capacities and a huge potential market. Large Western companies already took advantage of these opportunities by opening their own factories in China to build up local supply chains and address this new market, but this solution is not adapted to SME having very limited human and financial resources. Therefore new business models must be developed for them.

This paper presents a multicultural collaborative network of industrial SME including Swiss and Chinese partners. We will first describe the collaboration goals and context, identify the cultural differences affecting the choice of the Chinese network type, analyse the strengths and weaknesses of possible solutions and finally present the realized one.
\end{abstract}

\section{INTRODUCTION}

New industrial countries like China offer low work costs, large production capacities and a huge potential market. Large Western companies already took advantage of these opportunities by opening their own factories in China to build up a local supply chain and address this new market, but this solution is not adapted to SME having very limited human and financial resources. Therefore new business models based on collaboration must be developed for them.

This paper presents the results of a recent research project aiming at creating a multicultural collaborative network of industrial SME including Swiss and Chinese partners. We will first describe the collaboration goals and context, identify the cultural differences affecting the choice of the Chinese network type, analyse the strengths and weaknesses of possible solutions and finally present the realized one.

\section{COLLABORATION GOALS AND CONTEXT}

Swiss Microtech (SMT) is a network of seven independent SME active in the screw machining industry (Pouly et al., 2002). They produce parts for the automotive, medical, space and telecommunication sectors and export $90 \%$ of their production. Swiss Microtech has always wanted to be proactive and be prepared to address the current market needs by adding further production capacities in a fully flexible way and outsourcing parts that can no longer be produced in Switzerland in order to survive in a very fierce competitive environment. SMT also wanted to be able to 
"follow" important customers in China through local production and to address the Chinese market, which is considered by the financial analyst community as one of the main future global players.

As the parts produced by Swiss Microtech often require the collaboration of different partners bringing specific technologies and know-how and because of the results reached by the network in Switzerland (Pouly et al., 2005), the creation of a partner network in China looked like a very promising solution with real win-win content:

- SMT could outsource the parts, which cannot be produced in Switzerland for price or capacity reasons to the Chinese network, which would get new orders and profit from the worldwide sales organization of SMT

- SMT could "follow" an important customer to China with the partner network acting as a local proxy. In this case, most parts will be produced in China, some others in Switzerland, but all parts will be delivered by the Chinese network. Swiss Microtech would then be able to produce in China without having to invest all the necessary resources to plan, install, start and operate an own local factory, resources which are beyond the possibilities of small SME like the SMT members.

- Actual and future Chinese markets will be addressed by the local Chinese network that would sell its own parts but also some special parts it is not (yet) able to produce locally and that can be made by SMT.

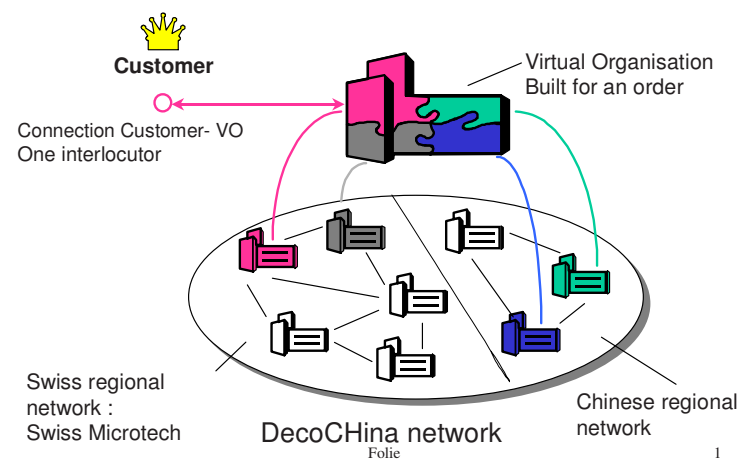

Figure 1 - The DecoCHina network

\section{CULTURAL KEY FACTORS FOR CHINESE CNO'S}

First of all, we will evaluate the cultural differences, which will influence the choice of the best suited type of network and the way of communication with Chinese companies (Greber, 2006).

\subsection{Trust issues}

In China, the definition and perception of "trust" is not the same like the one in western countries, where we are used to be open and to trust everybody under 
certain circumstances. Such a relation in China is mainly limited to family members or close friends of the family. A trust relation in China is much more complicated and very difficult to obtain between two companies as there are three different forms of trust, of which mostly the last one appears in business relations:

\section{Path trust}

Path trust is based on an individual's understanding of how another person will act in a certain situation. The feeling of having a common "path" relates each other and creates trust. As it is strongly linked to individuals, it isn't long lasting between companies, especially with the high employee turnover in China.

\section{Situation trust}

Situation trust is created when people do an activity based on common interests, hobbies or habits. In the process of doing this activity, the involved people shape a shared psychology, which is the foundation of trust among individuals. As this trust can be of relatively short duration, it is delicate for long-term relations between companies.

\section{Family trust}

Family trust is a strong trust among family relatives, which is tied by blood and is strengthened by mutual social connections. It is a very valuable and efficient trust system in the early development stage of enterprises. It facilitates the common interests among company members and helps them to reach an agreement on management goals. It is by far the main trust system in China's small and medium size companies (up to 1000 employees). Foreigners are of course not considered as family members.

\subsection{Tendency to hierarchy}

Due to China's history, people are used to live within clear hierarchical structures. This is also reflected in the relations within a network where usually one of the members grows much faster than the others and takes automatically the leader's position. In this situation the leader will develop itself further, while the other's growth will be naturally damped and it's very rare to see balanced relations between companies. Without this leadership of one of its members, the structural organization of the network would be difficult, especially if the network should be developed out of suppliers-customers relations, as it is hard to bring all the members on the same level. In some situations, the smaller companies of the network even prefer to stay under the protection of the biggest, for example in case of requests from foreign customers. Their English language skill level is often low and it would take a big effort to assure a direct communication between the small network members and the foreign customers.

\subsection{Immediate profitability}

Usually, business relations in China are much stronger linked to a direct profit than in Switzerland. The motivation for collaboration can almost only be created with an important order as a start point. The companies have to feel that they can take profit of this order by joining the network. The time between an investment and its revenue has to be very short. It is doubtable whether a cost reduction by commonly buying machines or material and sharing information about suppliers or technical issues is enough "profit" to raise their motivation. The duration of the motivation is also much shorter than in Switzerland. As soon as the direct profit is over, the 
relations would break. A feeling of togetherness based on a passed common business does usually not exist in China.

\subsection{Interest larger than competences}

In China, an order can easily be subcontracted 3 or 4 times. The companies take an order even if it is out of their competences and then they will find a partner for subcontracting. This partner itself may subcontract it again. It does not only slow down the request for quotation process but it also shows that it's extremely difficult to evaluate the real competences of a company. Furthermore, the traceability of an order is very difficult to maintain. Within a peer-to-peer network this could be a very difficult point if many companies want to take the same order.

\subsection{Importance of the prestige (face)}

The good image of each person and of their companies is very important and its loss must be avoided under any circumstances. If something is going wrong, it will probably not be spoken about. That means that not receiving any news does not necessarily mean that everything is running well. Face keeping is also important in the relation between people and attention has to be paid that a question should never risk affecting the other's prestige. For persons who don't have any experience with the Chinese culture, it can be very difficult to estimate the credibility of an answer.

\subsection{Communication}

Beside the cultural differences, the language is often a communication barrier. The average English language skill level in Chinese SME is rather low. In Chinese local companies it is not an exception that nobody has a sufficient level for technical discussions. Very often a translation by a third person is needed. As the cultural and technical references are quite different, explicit communication must be used as things, which are evident for Swiss companies, are not for Chinese ones and vice versa.

\section{CHOICE OF THE NETWORK STRUCTURE}

We will compare three potential solutions with the help of SWOT (Strengths, Weaknesses, Opportunities and Threats) analysis. In the first solution we don't have a network structure and sporadic subcontracting relations between companies can be formed. The second solution is a hub-and-spoke network, where close relations between the members and the central company are formed but not between the members themselves. In the third solution we find a peer-to-peer network structure, where all member companies are strongly linked to each other.

Advantages of virtual networks are largely discussed in the literature (Bruetsch et al.,1998). In the following SWOT analysis we focus on the compatibility to the Chinese environment and on a future collaboration with SMT. The goal is to find out if one of the two network structures is well adapted or if traditional subcontracting relations are the only solution. The main criteria for the following analysis are:

- Trust issues 
- Tendency to hierarchy

- Direct profitability

- Rapid change of motivation

- Competences estimation (partner selection)

- Communication

- Legal issues

\begin{tabular}{|c|c|}
\hline $\begin{array}{c}\text { An: No network: } \\
\text { relations }\end{array}$ & $\begin{array}{c}\text { B: Hub-and-spoke } \\
\text { network: } \\
\text { Network relations, but } \\
\text { only passing through a } \\
\text { central company }\end{array}$ \\
\hline
\end{tabular}

Figure 2 - Network forms

\subsection{Only subcontracting relations}

This classical solution is based on sporadic outsourcing relations when a need occurs. Partners must be chosen among a very large base of companies and as everything changes very quickly in China, past experiences may be not relevant.

\begin{tabular}{|l|l|}
\hline \multicolumn{1}{|c|}{ Strengths } & \multicolumn{1}{c|}{ Weaknesses } \\
$\begin{array}{l}\text { Trust: } \\
\text { No deep trust relations needed for } \\
\text { collaboration. }\end{array}$ & $\begin{array}{l}\text { Communication: } \\
\text { Very difficult communication with Chinese } \\
\text { Tendency to hierarchy: } \\
\text { clearly defined structure during the } \\
\text { collaboration. }\end{array}$ \\
$\begin{array}{l}\text { cultural differences. Contact to many } \\
\text { companies not possible. }\end{array}$ \\
$\begin{array}{l}\text { Each collaboration leads directly to a } \\
\text { financial profit. High motivation of } \\
\text { Chinese companies. }\end{array}$ \\
$\begin{array}{l}\text { Rapid change of motivation: } \\
\text { No long-term bonds and therefore no } \\
\text { consequences if the motivation of a partner } \\
\text { changes. }\end{array}$ \\
$\begin{array}{l}\text { Especially for foreign customers, very low } \\
\text { legal protection because of direct } \\
\text { collaboration with Chinese companies. }\end{array}$ \\
Choice of partners: \\
\hline
\end{tabular}




\begin{tabular}{|l|l|}
\hline \multicolumn{1}{|c|}{ Opportunities } & \multicolumn{1}{c|}{ Threats } \\
$\begin{array}{l}\text { Simplicity } \\
\text { Simple customer-supplier relations }\end{array}$ & $\begin{array}{l}\text { Competences estimation: } \\
\text { Difficulties for customers to know if a } \\
\text { supplier is able to fulfill the requirements, } \\
\text { or if it will further subcontract. }\end{array}$ \\
& $\begin{array}{l}\text { Local support: } \\
\text { No support at all, the foreign company must } \\
\text { monitor the quality and delivery schedules } \\
\text { itself }\end{array}$ \\
\hline
\end{tabular}

\subsection{Hub-and-spoke network}

This solution is based on a very centralized network of suppliers where the hub is the main contact to the foreign company. The hub is responsible for selecting, assessing and continuously monitoring its own suppliers as well as for the respect of quality and delivery schedules.

\begin{tabular}{|c|c|}
\hline Strengths & Weaknesses \\
\hline $\begin{array}{l}\text { Legal aspects: } \\
\text { Protection of foreign customers because } \\
\text { the orders are given only to the hub and } \\
\text { because of the high pressure on the } \\
\text { member companies due to follow-up } \\
\text { orders. } \\
\text { Communication: } \\
\text { Existence of an intermediate element } \\
\text { between foreign customers and local } \\
\text { Chinese companies. This allows an access } \\
\text { to a higher number of suppliers } \\
\text { Direct profitability: } \\
\text { From the beginning on the member } \\
\text { companies feel the profit in form of direct } \\
\text { orders. Important point to increase the } \\
\text { motivation. } \\
\text { Tendency to hierarchy: } \\
\text { Clear organization because of hierarchic } \\
\text { structure. } \\
\text { Rapid change of motivation: } \\
\text { If one member company jumps off, the } \\
\text { motivation of the others is not affected. } \\
\text { Local support: } \\
\text { Strong local support as only the hub is } \\
\text { responsible for the orders }\end{array}$ & $\begin{array}{l}\text { Trust: } \\
\text { Difficult to build trust between a member } \\
\text { company and the hub company, if they are } \\
\text { not family-related (does not affect a } \\
\text { foreign customer of the network.) }\end{array}$ \\
\hline $\begin{array}{l}\text { Opportunities } \\
\text { Competences estimation: } \\
\text { Customers have access to information } \\
\text { about member's competences due to the } \\
\text { experience of the hub company. }\end{array}$ & $\begin{array}{l}\text { Threats } \\
\text { Rapid change of motivation: } \\
\text { The hub company is the centre of the } \\
\text { network. A loss of its motivation would } \\
\text { have drastic consequences. }\end{array}$ \\
\hline
\end{tabular}




\subsection{Peer-to-Peer Network}

Peer-to-peer networks are based on the collaboration of independent companies on the same level of hierarchy. As there is no central power, the decisions must be negotiated between the members and an acceptable consensus must be found.

\begin{tabular}{|c|c|}
\hline Strengths & $\begin{array}{l}\text { Weaknesses } \\
\text { Legal aspects: } \\
\text { Especially for foreign customers, very low } \\
\text { legal protection because of direct } \\
\text { collaboration with all member companies. } \\
\text { Communication: } \\
\text { Very difficult communication with } \\
\text { Chinese companies due to low language } \\
\text { levels and cultural differences. Contact to } \\
\text { many companies not possible. } \\
\text { Direct profitability: } \\
\text { Direct financial profit in form of orders } \\
\text { after a long initialization period of the } \\
\text { network. In the beginning only economies } \\
\text { of scale. } \\
\text { Trust: } \\
\text { Very difficult to build trust within a group } \\
\text { of companies which are not family related. }\end{array}$ \\
\hline Opportunities & \begin{tabular}{l}
\multicolumn{1}{c}{ Threats } \\
Competences estimation: \\
Large and similar core competences \\
between members. Leads to conflicts \\
during the order distribution. \\
Tendency to hierarchy: \\
Difficulties to obtain a structural \\
organization, as all companies are on the \\
same level. Risk that the stronger \\
companies wouldn't respect the weaker \\
ones anymore. \\
Rapid change of motivation: \\
If one member company jumps off, the \\
motivation of the others can be negatively \\
affected.
\end{tabular} \\
\hline
\end{tabular}

\section{CONCLUSIONS}

The message received during the discussions (among others with the Dongguan University of Technology and our industrial partners) was clear: Chinese companies are not yet ready to form peer-to-peer networks, even if this structure is widely seen as the most performing type of network. For the moment, the best solution in terms 
of cultural compatibility and intercontinental customer relations is the hub-andspoke type, with a strong and trustful company in the centre of the network.

As an example, the DecoCHina extended network has been created in 2007 with Swiss Microtech and a local Chinese company located in the Province of Guangdong and having both local and Western management as the hub that also brings its own network of around ten local companies (Pouly et al.,2008). This hub company is for the moment the only contact of Swiss Microtech and it takes also the responsibility of its own suppliers. First commercial activities involving both partners are currently on the way.

\section{ACKNOWLEDGEMENT}

The authors would like to thank Mr. Xu Bing from Dongrui Ltd in Dongguan, Professor Mo and Professor Quan from the Dongguan University of Technology (DUT) for their commitment and support. The authors would also like to thank the Dongguan Bureau for Science and Technology and the Commission for Technology and Innovation of the Swiss federal government, which funded this research.

\section{REFERENCES}

1. Bruetsch D. et al., Virtuelle Unternehmen, v/d/f Hochschulverlag an der ETH Zürich, 1999

2 .Greber M.; Master thesis, Optimization of the business processes within a Swiss-Chinese collaborative network and development of an assessment methodology for new members, EPFL; 2006

3. Pouly M. , Glardon R, Huber C. , Competitor based strategic networks of SME, in Knowledge and Technology Integration in production and Services, pp 149-156, edited by V .Marik, L. CamarinhaMatos, H. Afsarmanesh, Kluwer Academic Publishers, 2002

4. Pouly M., Greber M., Glardon R., Huber C., Beeler J., DecoCHina: A Swiss Chinese Industrial Collaborative Network of SME, to be presented at the IEEE CSCW08 Conference in Xian, China

5. Pouly M., Monnier F., Bertschi D. , Success and Failure Factors of Collaborative Networks of SME, in Collaborative Networks and their Breeding Environment, pp 597-604, edited by L. CamarinhaMatos, H. Afsarmanesh, A. Ortiz, Springer, 2005 